Open Access

\title{
Technology convergence, open innovation, and dynamic economy
}

Hang Sik Park

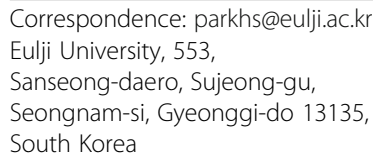

Correspondence: parkhs@eulji.ac.kr Eulji University, 553,

Sanseong-daero, Sujeong-gu,

Seongnam-si, Gyeonggi-do 13135

South Korea

\begin{abstract}
The world economy has been confronting low economic growth for several years. Many experts agree that concepts such as openness, convergence, and creation of new market demand through new emerging technologies (e.g. Internet of Things, big data, and Artificial Intelligence) may solve the current economic crisis throughout the world. When these concepts are linked to a network, the law of increasing returns will come true. As the issue of the 4th industrial revolution mentioned in the 2016 World Economic Forum is similar, the enlargement of open innovation and convergence will lead to a new dynamic economy and sustainable development.
\end{abstract}

Keywords: The fourth industrial revolution, Dynamic economy, Open innovation, Convergence, Disruptive innovation

\section{Introduction}

At the 2016 Davos Forum, Klaus Schwab, the president of the World Economic Forum (WEF), mentioned the Fourth Industrial Revolution as a disruptive innovation. Disruptive innovation means that our models and values are replaced with completely new ones.

In 2016, an event that AI(artificial intelligence) won a victory over one of the world's best Go playes in the world raised to inspire us with threat and fear.

Already, the world is advent of a hyper-connected society. The society will adapt to various sectors- such as medicine, transportation, manufacture, distribution and education- resulting in innovative change in the existing processes and services.

A new business model, such as a sharing economy and a small organization with rapid growth, will appear. By using Internet of Things (IoT) and location-based big data, it will be possible to make transactions that were not possible in the past. In addition, a sharing economy, whose marginal costs are minimized, such as Airbnb and Uber, will become more easily implemented. A sharing economy is an economic activity in which an article is not purchased but borrowed (P2P finance, P2P accommodation, online source, key waring, contents, streaming service, etc.)

As those new technologies emerge, it is expected that the technology will destroy the sequence of the value chain and will complexly combine value chains. Thus, the industrial ecosystem will change completely. It will break down the barrier of existing business types and have a large impact on upstream and downstream industries (Kim 2016).

(C) The Author(s). 2017 Open Access This article is distributed under the terms of the Creative Commons Attribution 4.0 International License (http://creativecommons.org/licenses/by/4.0/), which permits unrestricted use, distribution, and reproduction in any medium, provided you give appropriate credit to the original author(s) and the source, provide a link to the Creative Commons license, and indicate if changes were made. 
Now, the global economy is stuck in slow growth, with an average annual growth rate of $3.5 \%$. As the economic growth rate of some countries with large populations, such as China and India, exceeds 6\%, the global economy has managed to keep remain stable at $3.5 \%$. However, the United States, European countries, and Japan have showed low growth rates $-1.6 \%, 1.9 \%$, and less than $2 \%$, respectively. Korea also has a slow growth with less than $3 \%$ and is expected to grow by about $2.6 \%$ in 2017.

Then, what is the solution to overcome low growth?

The important thing is to create new demands and jobs for young people to revitalize the global economy. In the closed-innovation paradigm, technology policy has emphasized the supply side of development, but in the open innovation paradigm on the contrary, it must work on the demand side. The concept of "demand articulation" was effective in formulating corporate policies for technology and market development, and also in government policies for accelerating the commercialization process of emerging technologies (Kodama \& Shibata 2015).

Attempts to create a dynamic economy are collectively called the Fourth Industrial Revolution. So, in Chapter 2, we will examine about the Fourth Industrial Revolution and Dynamic Economy. As the technological change is the key of the Fourth Industrial Revolution, I would like to organize in this paper what are the major technologies, what the major countries are preparing to and already have. In Chapter 3, we will examine the relation of Open Innovation Paradigm on achieving the Dynamic Economy. In Chapter 4, we will focus on the meaning of the Dynamic Economy and Convergence, as the change of a new technology is not just an improvement of a single technology, but acutely requires the technological convergence. In Chapter 5, we would like to propose the direction of policy needed for the countries which desire to acquire the competitiveness on Dynamic Economy, Open Innovation, and Convergence.

\section{Fourth industrial revolution and dynamic economy}

In the Third Industrial Revolution, humans are closely linked with computers and machines to realize production automation. However, in the Fourth Industrial Revolution, smartization, in which computers and machines communicate interactively and independently by AI, is realized, as shown in Fig. 1.

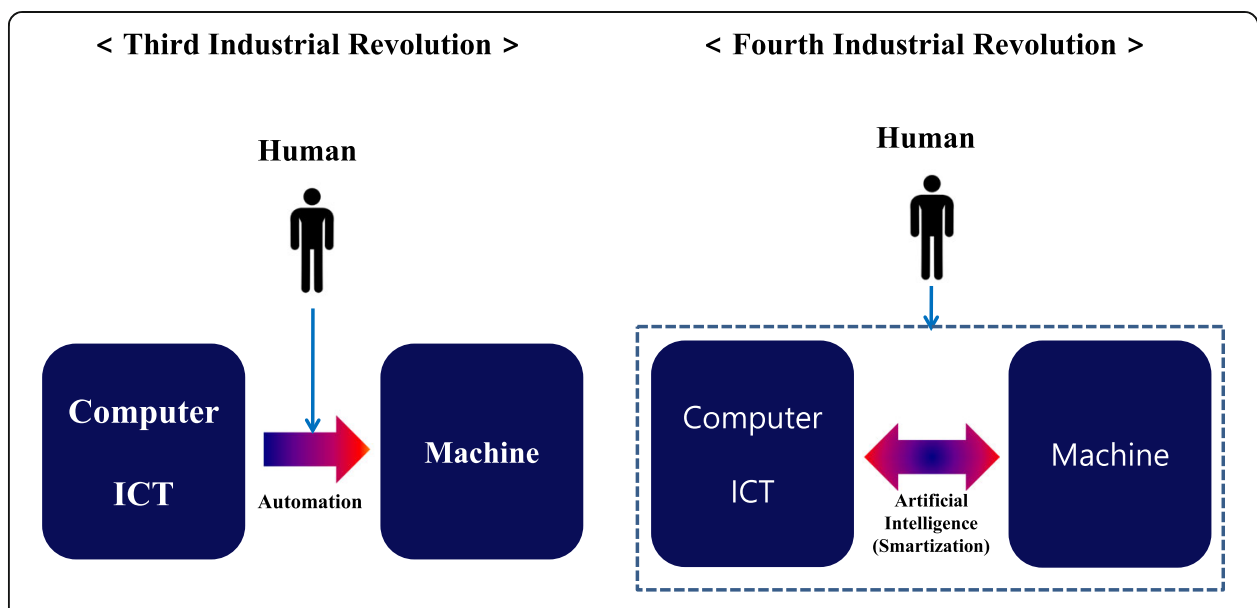

Fig. 1 Comparison of the Third and Fourth Industrial Revolutions 
The thing that makes this revolution clearly different from the existing industrial revolution is its speed and range. In particular, the explosive speed, which reaches an obsessive level, pushes our energies.

It is expected that the Fourth Industrial Revolution will have a positive impact on the creation of demand, that is, new businesses, brought about by new technologies. In other words, convergence with new technologies is expected to create new markets and jobs. The Fourth Industrial Revolution is defined as a technological revolution that fuses digital technology based on the Third Industrial Revolution, and physical and biological fields.

In this sense, the advanced technologies of the Fourth Industrial Revolution-such as autonomous vehicles, 3-D printing, the Internet of Things (IOT), and genetic engineering-lead disruptive innovation by fusing individual technologies in the fields of information and communications technology (ICT), as well as scientific techniques.

Jang (2016) concretely suggested 10 advanced technologies and 23 megatrends, and divided them into physical, digital, and biological categories, which are the three core fusion technology fields of the Fourth Industrial Revolution.

Among the various technologies, what is the most meaningful and promising field in the Fourth Industrial Revolution? As a system that networks cyber and physical worlds based on IoT and AI should be built, necessary base technologies and service technologies using cyber-physical systems (CPS) seem to be the most promising. The combination of business model creation, accompanied by the accumulation of big data and its advanced utilization, can make the arguments of market-driving more plausible, and make the accuracy of demand articulation more enhanced (Kodama \& Shibata 2015). For base technologies, it is expected that there will be a rapid increase in the demand for sensors that connect people, things, and spaces, as well as platforms that share and use various information and data (Park 2016).

(Sensor technology) As a device that acquires and analyzes information generated in the real physical world, sensors are likely to serve as a sensory organ of CPS. To implement an intelligent CPS, sensors are being applied to various fields such as measuring instruments, automobiles, mobile devices, home appliances, medical devices, and defense/security devices. In particular, as the interaction between humans and devices increases, the need for smart sensors that combine data-processing, decision-making, and communication functions with sensing functions ${ }^{1}$ are also rising. Therefore, we need to increasingly invest in devices for precise sensing, components that can generate the power of a sensor by themselves (piezoelectric elements, thermoelements, nanogenerators using frictional electricity), and embedded software.

(Platform technology) As the demand for analyzing and using information collected through sensors to provide customized services as well as intellectual assets accumulated in diverse organizations and companies, increases, and devices with sensors and user needs become diverse, it is essential to develop a platform that can integrate and manage data at once. In particular, with the success of companies that have created an ecosystem that provides unique services and contents by building their platform (Google's Android, Apple's iOS/iTunes (App Store), Amazon, Facebook), more attention is being paid to new businesses. Therefore, we need to continuously invest in cloud computing and AI / big data technologies as well as security technology, which are needed to operate a platform. In particular, we also need to promote a smart 
sharing/transaction system for personal integrated data and the formulation of related policies.

(Predictive maintenance) There is a growing interest in predictive maintenance services that can prevent the failure of a core facility or device, or the loss caused by the failure. As we can collect and analyze various data generated from facilities and devices, it is possible to secure a plan to maximize operational performance. In addition, this service can prevent the shutdown of production lines; predict the abnormality of automobiles and home appliances, and help in solving the problem. Therefore, the ability to secure technologies related to real-time monitoring sensors and big data as well as data that can predict the remaining service life of parts is growing in importance.

What are the capabilities of the world's major nations in the Fourth Industrial Revolution, and which countries are preparing well for the revolution? To this end, Lee (2017) diagnosed the added value status in the ICT and ST (science and technology intensive) fields by using statistics from 2014 and their trends as well as the fusion between national industries by using the World Input-Output Table (WIOT).

The ICT industry of the United States has an added value sector worth USD 1074.2. This figure accounts for about one-third of the nations analyzed (33.2\%), followed by China (8.4\%), Japan (6.6\%), and Germany (5.2\%).

In the case of the ST industry, Japan, which is struggling to escape from its economic downturn, forms $21.1 \%$, which exceeds the figure of the United States, and ranks 1st.

When the ICT and ST fields are combined, the United States ranks 1st (29.4\%), followed by China and Japan, which have similar figures (shown Table 1).

In terms of the value-added ratio, Table 2 shows that the United States ranks 1st in the ICT sector (57.6\%), and Japan is 1st in the ST sector (70.6\%). If the ICT and ST fields are added, Japan ranks 1st (62.3\%), followed by the United States and Germany.

In terms of the convergence of the ICT -and ST sectors among the national industries, the United States, Japan, and China immediately input their ICT and ST fields in all 33 industries (over 95\%). However, Germany inputs about 57.2\%-90.0\%, while Korea inputs about $69.0 \%-94.0 \%$. It is believed that there is a large deviation between industries.

For each industry, the input of the ICT and ST sectors in the service business is larger than that in the manufacturing industry. The professional business support industry has the highest input (Lee, 2016).

The Union Bank of Switzerland (UBS) assessed the adaptation level of the Fourth Industrial Revolution, which has targeted 139 nations, by considering five factors: labor

Table 1 Ratio of the ICT and ST Sectors of Global Major Powers and Their Trends (\%)

\begin{tabular}{|c|c|c|c|c|c|c|}
\hline & \multicolumn{2}{|l|}{ ICT } & \multicolumn{2}{|l|}{ ST } & \multicolumn{2}{|l|}{$\mathrm{ICT}+\mathrm{ST}$} \\
\hline & $\begin{array}{l}\text { Ratio of } \\
\text { Domestic } \\
\text { Industries }\end{array}$ & $\begin{array}{l}\text { Average } \\
\text { Growth Rate }\end{array}$ & $\begin{array}{l}\text { Ratio of } \\
\text { Domestic } \\
\text { Industries }\end{array}$ & $\begin{array}{l}\text { Average } \\
\text { Growth Rate }\end{array}$ & $\begin{array}{l}\text { Ratio of } \\
\text { Domestic } \\
\text { Industries }\end{array}$ & $\begin{array}{l}\text { Average } \\
\text { Growth Rate }\end{array}$ \\
\hline United States & 33.2 & 4.4 & 17.6 & 4.1 & 29.4 & 4.4 \\
\hline Germany & 5.2 & 5.5 & 4.1 & 5.6 & 5.0 & 5.5 \\
\hline Japan & 6.6 & 0.5 & 21.1 & 1.1 & 10.2 & 0.8 \\
\hline China & 8.4 & 19.5 & 16.1 & 22.9 & 10.3 & 20.7 \\
\hline Korea & 1.5 & 5.8 & 3.5 & 10.7 & 2.0 & 7.5 \\
\hline
\end{tabular}

Source: Lee, S.-Y. (2017). 419 
Table 2 Value-Added Ratio of the ICT -and ST Sectors of Global Major Powers(\%)

\begin{tabular}{lllllll}
\hline Category & United States & Germany & Japan & China & Korea & 43 nations \\
\hline ICT & 57.6 & 53.2 & 55.5 & 55.0 & 43.5 & 55.1 \\
ST & 58.4 & 60.2 & 70.6 & 44.4 & 59.3 & 54.6 \\
ICT + ST & 57.7 & 54.5 & 62.3 & 50.4 & 49.1 & 55.0 \\
All Industries & 56.0 & 49.3 & 51.2 & 32.4 & 37.8 & 45.8 \\
\hline
\end{tabular}

Source: Ibid. (2017). 42

market flexibility, technology level, educational system, social overhead capital, and legal protection (Baweja et al., 2016). Lee (2017) released the results of reassessing the adaptation level, targeting only the top 45 nations among them.

The adaptation level of each nation is an index that indirectly shows future competitiveness. According to the results, Switzerland ranks 1st, followed by Singapore and the Netherlands. The United States ranks 5th; Japan, 12th; Germany, 13th; and Korea, 25th. In particular, Korea overall lacks preparation for the Fourth Industrial Revolution when compared with advanced nations. In each element of the Korean adaptation level, the educational system (17th), technology level (20th), and social overhead capital (20th) are higher than the general ranking, but legal protection (29th) and labor market flexibility (34th) are relatively lower, as shown in Fig. 2.

Then, what are the strategies of companies, industries, and nations to wisely handle the waves of the Fourth Industrial Revolution, which has a high possibility to lead the dynamic economy? I think the key is open innovation and convergence. The reason is that, as the Fourth Industrial Revolution leads disruptive innovation, the technologies you have or developed need to be open to fusing with the digital, physical, or biotechnology fields.

\section{Dynamic economy and open innovation}

Open innovation stresses the importance of the external knowledge activity of a company during the innovation process. To handle the rapidly changing environment, as the use only of internal corporate knowledge has limitations, external

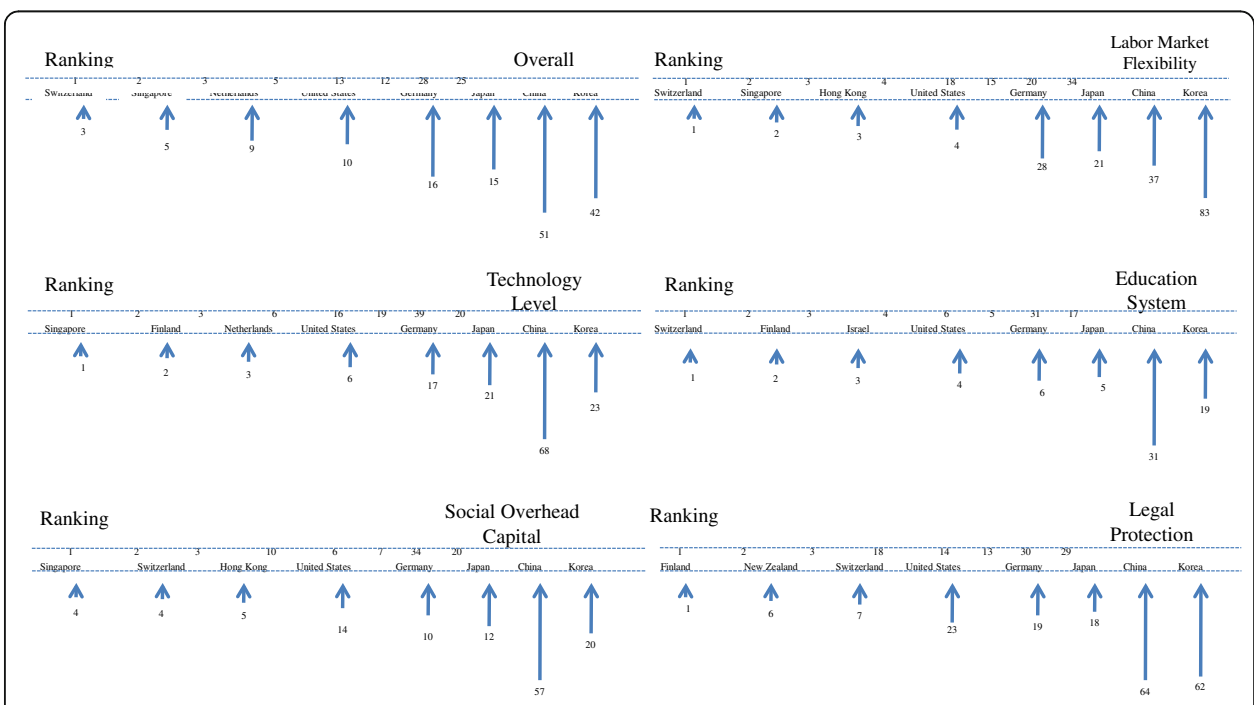

Fig. 2 Adaption Level of the Fourth Industrial Revolution 
knowledge can be used so that the company's innovation activity performance can be improved (Chesbrough, 2003). Continuously seeking openness in acquiring new knowledge can lead to creativity (Yun, Park, Yang and Jung, 2016, b).

Firms are increasingly utilizing not only their own technolgies, but also external knowledge and other technologies. In addition, the open innovation phenomenon is rapidly spreading into many industries, nationwide, and worldwide, as firms provide their unused technologies to be utilized by others. The dynamic model of open innovation linked logic and concepts relating to open innovation,comlex adaptive systems, and evolutionary change(Yun, Won and Park 2016).

For values created through the information and communication network, "Metcarfe's Law," which was suggested by Robert Metcalfe, the founder of the Ethernet, is a noticeable principle. As values exponentially increase with the number of network users, the values of billions of people connected through the Internet network are enormously larger than those provided through the local area network. As more and more people become connected with each other, more values are given to network members (Laursen \& Salter, 2006).

The Coase theorem can also describe the impact of technological development on economic players. According to Ronald H. Coase, a Nobel Prize-winning England economist, if transaction costs decrease, corporate complexity will simplify. Thus, companies tend to expand their size until the transaction costs generated when additional unit products are internally produced become equal to those generated when the manufacturing process is externally outsourced (Coase, 1937).

In other words, if the cost of production in a company increases, thus decreasing cost efficiency, compared with the situation in which products are externally purchased, or if the transaction costs generated to secure necessary resources from the outside due to the development of the information and communication network sharply reduces and are lower than the cost of production in a company, the company necessarily selects outsourcing.

Since the beginning of history, there has been a trade-off between the range of information dissemination and the quality of information. However, the Internet-based network successfully eliminates the relation. The Internet does not have a limitation on the quality of information disseminated, thus making a huge contribution to the creation of global networks (Lee and Olson, 2011).

For the economic principle of network, Kevin Kelly (1997), the CEO of a headhunting company, stated the following will take place:

(1) The dynamic network economy creates wealth from "innovation" rather than optimization.

(2) Unknown value creation builds a network environment that allows quick access to information.

(3) You should give up a well-known thing to occupy an unknown thing in advance.

(4) As the network economy develops the "development-maturation-destruction" cycle becomes faster (Kelly, 1997).

One of the cases of this principle is Amazon.com. Amazon.com, which had been in the red for a long time, struggled in overcoming the situation and rapidly expanded its 
size after reaching the tipping point. Finally, it was able to make profits. Now, it promotes the formation of a new network, such as drone parcel delivery services. Network creation can also be linked to the law of increasing returns. In addition, it is similar to the "economic development through creative destruction" mentioned by Schumpeter.

Other examples are IBM and Apple. Recently, biological fields, such as molecular biology and new medicine, have started to pay attention to this principle.

The typology of the changes caused by the activation of outsourcing due to the development of digital technology is described as follows (Lee et al., 2011):

(1) Population migration: High-quality human resources move to advanced nations.

(2)Changes in the industrial structure: Automation and knowledge-intensive industries (e.g., BT, pharmacy, information and communication, education, financial service) grow and create new values or wealth.

(3)Deregulation: The aviation and telecommunications industries provide hugely improved services and economic benefits to consumers.

(4) Process generalization/standardization: By building a platform that integrates ecommerce solutions, the work process and customer satisfaction services can be given to customers, even without handling them in person, such as India's tax report program or Nighthawk's X-ray reading work.

(5)Creation of new value chains: By connecting with global partners through diverse supply chains through e-commerce, cheap, but high-quality, products can be given to customers to provide larger values (e.g., Walmart).

In addition, the changes caused by the Fourth Industrial Revolution, which will lead the dynamic economy, can be added.

(6) The Fourth Industrial Revolution (New Economy model): This revolution leads a convergence revolution beyond the boundaries of areas so that the convergence of two different areas leads to the innovation of a new business (e.g., AI, web technology)

Several studies have proved that innovation is an important factor in the growth of venture companies (Kang, Lee, \& Oh, 2012). In particular, venture firms are relatively small, and their internal resources are limited. Thus, using external resources is highly essential for the innovation performance of venture companies.

Chae, Chio and Huh (2014) compared and analyzed the open innovation status of venture firms and non-venture firms by using the technology innovation survey (STEPI, 2012). According to the comparison and analysis results, venture firms searched for external knowledge more extensively and in-depth on average than non-venture companies. In addition, venture firms performed more product, process, and organizational innovation activities on average.

However, when external knowledge is divided into external search breadth and external search depth, in terms of organizational innovation performance, both have a positive impact on the organizational innovation performance of venture firms, just like non-venture companies. ${ }^{2}$ According to the research results, in the case of general venture firms, whose size is small and whose resource use is limited, the intensive and in-depth search of external knowledge by using limited resources is more helpful 
for the innovation performance of products and processes than the extensive search of external knowledge (Chae et al. 2014). This study result shows that the open innovation strategy plays an important role in the innovation performance of venture companies.

\section{Convergence and dynamic economy}

Many experts have argued that the source of competitive edge has moved from "economy of scale" to "economy of scope" to "economy of expertise" to "economy of convergence" (Lee et al. 2011). To implement the dynamic economy, the digital, physical, and biological sectors-which are the characteristics of the Fourth Industrial Revolution-should be actively converged. Through convergence, we need to open the possibility of creating new values. In the past, digital technology was a target for convergence. However, in the future, it is expected that technology will serve as a catalyst to boost creative convergence.

Let's look at some successful convergence cases in the past.

Nike, which is famous for sports shoes, does not manufacture shoes. It creates demand by promoting its brands on a large sale with star players and secures its product markets through global suppliers connected through the Internet. This case shows that the Internet environment is important (Ghemawat, 2007).

Walmart forms supply chains with global suppliers and uses big data for data mining in a way similar to Carrefour. By connecting to the decision-making support system, Walmart purchases high-quality products at a minimum cost to secure its cost competitiveness (Ghemawat, 2007).

These cases show that the "creative destruction" mentioned by Schumpeter actually occurs. The genetic manipulation of an organism allows for the development of antibiotics and medicines for gene-related diseases as well as the combination of nanotechnology and biotechnology, thus leading to the creation of electronic nanocomputers.

In the Fourth Industrial Revolution, we can be customers, even though we do not actually use a product or service nor have any physical experience of using a product or service. A person who can possibly be a customer in the future, even though he/ she is not a customer now, should be included in the scope of a customer. We need to create demand by converging a technology and a new method, and to explore new markets. The new convergence innovation strategy is the combination of exploitation (i.e., using a well-known thing) and exploration (i.e., exploring an unknown thing). Access methods can be classified as shown in Fig. 3.

Successful convergence examples can be classified into three types (Lee et al. 2011) as follows:

(Convergence of products) New customer values-such as additional functions, convenience, cost reduction, efficient use of spaces, pleasure and comfort, and safety-are provided. Some examples are a camera and a mobile phone, a vehicle and a navigation system, and a washing machine and a dryer.

(Convergence of a product and a service) Some examples are General Motors corporation (GM) and GM Telematics, and Apple iPod and the music download service exclusively for iPod users.

(Convergence of services) Some examples are various package services including amusement parks, hotels, resorts, and golf courses-like KT Bismeka ${ }^{3}$ and Disney 


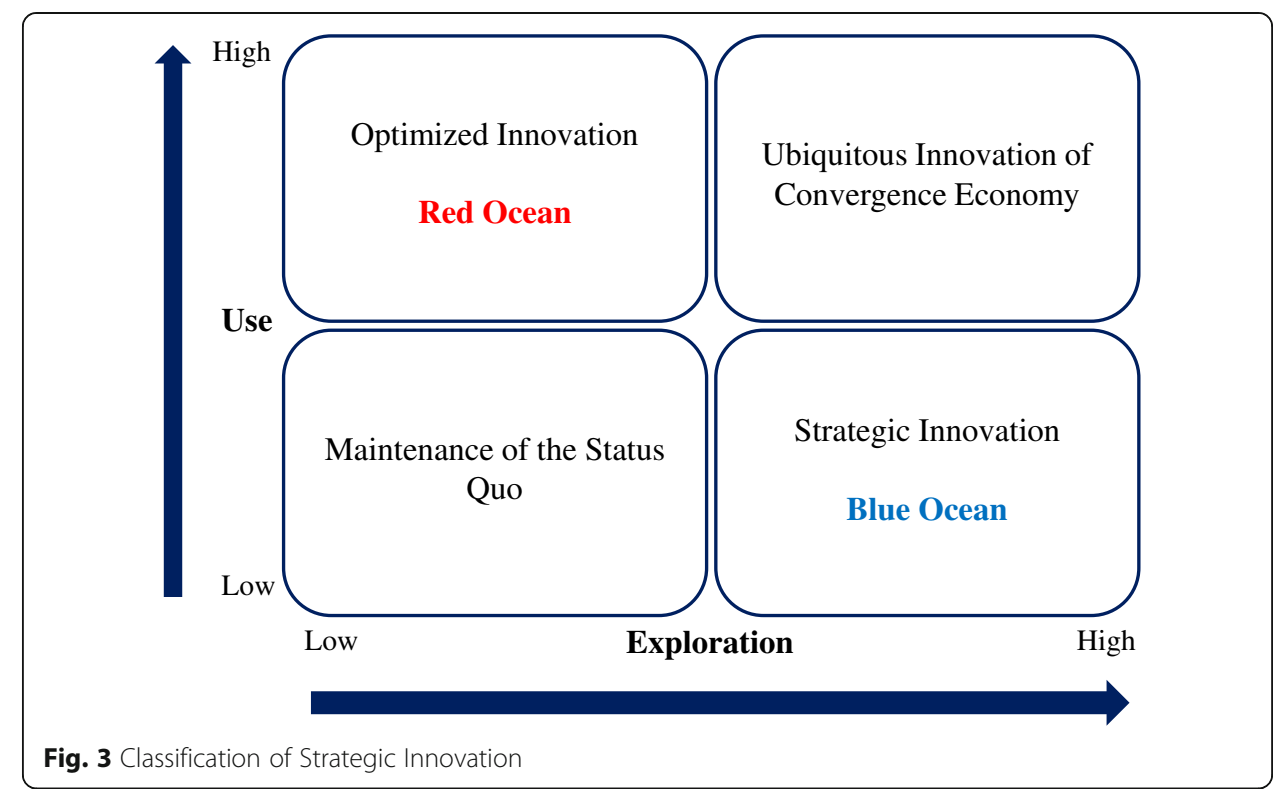

World-and combinations of accommodations, recreation centers, shops, schools, and restaurants like U-Community.

Convergence is not a simple dichotomy, like yes and no. It is a process of applying the blue ocean strategy including removal, reduction, growth, and creation. Removal is eliminating elements that cannot give values. Reduction is decreasing the provision only of limited values. Growth is intensively improving a thing that a customer values. Creation is providing customers with good values and expanding the customer base.

\section{Implications for policy direction}

We have examined the connection between open innovation and convergence for the dynamic economy that will come in the Fourth Industrial Revolution. What is the policy direction that realizes the connection of the abovementioned three words in depth?

I have already mentioned at the end of the Chapter 2 that as the Fourth Industrial Revolution leads the Disruptive Innovation, the need of openness by convergence of digital, physical, biological fields is necessary. Also, in Chapter 3, it is also mentioned that the open innovation is the key to smooth a new innovation that the market craves. As for the business, the usage of external knowledge is important due to the limit of internal corporate knowledge, the interest in open innovation on process is increasing. In case of venture firms, it is identified that competitiveness on the product, process and organizational innovation activities by the external knowledge are getting higher (Chae, et al. 2014). Lee and Olson (2011) have proved the importance of the creation of global networks on the development of the internet. They have insisted that to promote the open, we need to resolutely deregulate the existing regulations which might disturb.

In Chapter 4, the Economy of Convergence has been also emphasized. The importance of education on sensitiveness is being emphasized as the Creative Destruction by Schumpeter or the needs of the new customers is not about utilizing the existing knowledge, but to use creativity, and the newly-made needs are not naturally made but to be created. 


\section{1) Deregulation of new businesses.}

In general, companies have competed most efficiently in free markets without artificial restrictions. Although they may compete, they are also capable of collaborating to create something of commercialisable social value. It is like "dark material" in the universe, all around us but difficult to see. Entrepreneurs and innovators are largely responsible for such "dark material" (Cooke 2016). Several governments have focused on eliminating regulations or interferences as much as they can to encourage innovation and promote industrial development. The most recent example is the changes in the industrial environment caused by deregulating the aviation and telecommunications industries of the United States (Lee \& Olson 2011).

AT\&T, which held a monopoly in the telecommunications industry, competes with other companies due to deregulation. The technical development of phone services has also led to the expansion of the Internet, which allowed for the exchanges of voice calls and data for free with phone companies and customers, and of mobile technology (Apple's smartphones).

In addition, the cost deregulation of the aviation industry allows the use of databases for demand, price elasticity, and service cost. Thus, airline ticket prices are flexible (depending on the time, day, and airline company), and customers can have economic benefits.

The Regulatory Reform Committee in Korea (2016) announced the diverse deregulation policies of the Korean government to improve the competitiveness of new businesses (e.g., drones, self-driving cars). It is expected that these deregulations will also be promoted by the new government.

2) Expansion of new human resources (the human equation).

In the management in the twentieth century, the workforce was considered as a cost to decrease. People focused on how much the workforce could be substituted with simple and efficient computer technology. However, in the twenty-first century, it is expected that human resources will become a key factor. Future management needs the understanding and exploration of strong points, interest, and knowledge of organization members.

In order to secure the expertise of knowledge labor, it is necessary to acquire the latest information and business knowledge as well as to devote oneself to work activities to improve the value of an organization. Knowledge workers and executives should fulfill their common mission to meet customer requirements by breaking away from the conflicts between labor and management (dichotomy).

It is true that there is growing concern about employment in the Fourth Industrial Revolution. However, the decrease in the employment market in the information era of the Third Industrial Revolution was not much of a problem. Bank clerks were rarely employed with the introduction of automated teller machines (ATMs). In Silicon Valley, the employment of skilled workers with new technologies increased depending on the region. However, it is expected that the middle-skilled workforce will shift significantly to low- or high-skilled work (shown in Fig. 4).

Recently, the Korean government announced the direction of educational reforms for the Fourth Industrial Revolution (Ministry of Education 2016). As the new Korean government takes office, educational reforms will change. But the conditions for improving the educational system of universities in Korea will be maintained according to the current situation. 


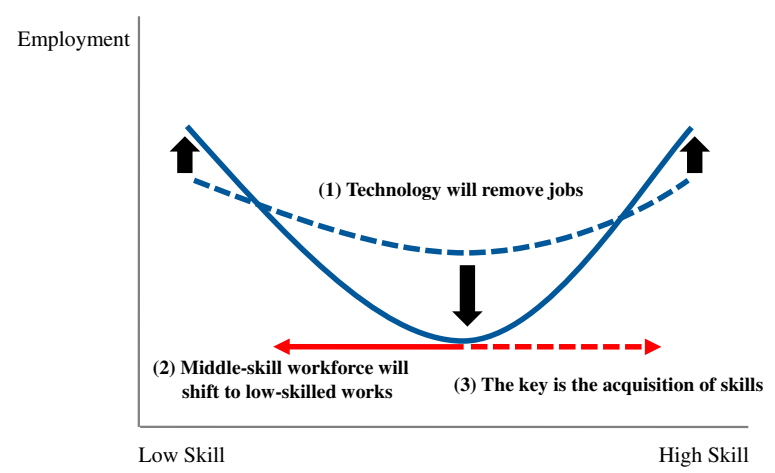

Fig. 4 Change of Employment Type due to the Fourth Industrial Revolution

3) Support of new convergence technology.

Convergence technology that will be developed based on digital technology should be supported in a way that is different from the past. As disruptive innovation is needed, technology should be developed, but led by the private sector. In addition, the government should strengthen the support of technologies that cannot be supported by the private sector as there are no basic technologies or profits.

As shown in the Table 3, we need to develop key technologies in the physical, digital, and biological fields, but individual and new technologies, as well as convergence cases between products and services, should lead the creation of business models as well as the commercialization of new technologies and products.

4) Increase in the support of venture companies for their external knowledge search.

According to an empirical study recently conducted, for product and process innovation activities, as the external search depth has a more positive impact on corporate products and processes and on organizational innovation performance than external search breadth, we need to support domestic venture companies to allow them to search for diverse external knowledge in depth, and not be limited to internal knowledge (Chae et al., 2014).

Although the result are different for each industry, as demand from companies and customers are important as external knowledge sources, and as colleges and governmentfunded research institutes-which are intensively supported-are not relatively important, it is recommended that, when the Korean government supports the policies for the Fourth

Table 310 Advanced Technologies and 23 Megatrends in the Fourth Industrial Revolution

\begin{tabular}{|c|c|c|c|}
\hline & Physical & Digital & Biological \\
\hline $\begin{array}{l}\text { Advanced } \\
\text { Technology }\end{array}$ & $\begin{array}{l}\text { 1. Autonomous vehicles } \\
\text { 2. 3-D printing } \\
\text { 3. Advanced robotics } \\
\text { 4. New materials }\end{array}$ & $\begin{array}{l}\text { 5. loT, remote monitoring } \\
\text { technology } \\
\text { 6. Block chain and bitcoin } \\
\text { 7. Sharing economy and } \\
\text { on-demand economy }\end{array}$ & $\begin{array}{l}\text { 8. Genetic engineering } \\
\text { 9. Synthetic biology } \\
\text { 10. Bioprinting }\end{array}$ \\
\hline Megatrends & $\begin{array}{l}\text { 1. Implantable } \\
\text { technologies } \\
\text { 2. Digital presence } \\
\text { 3. Vision as a new interface } \\
\text { 4. Wearable Internet } \\
\text { 5. Ubiquitous computing } \\
\text { 6. A supercomputer } \\
\text { in your pocket } \\
\text { 7. A storage for all } \\
\text { 8. Internet of things }\end{array}$ & $\begin{array}{l}\text { 9. Connected home } \\
\text { 10. Smart cities } \\
\text { 11. Big data for decisions } \\
\text { 12. Seif driving cars } \\
\text { 13. Artificial intelligence } \\
\text { and decision-making } \\
\text { 14. Al and white-collar jobs } \\
\text { 15. Robotics and services } \\
\text { 16. Bitcoin and the block chain }\end{array}$ & $\begin{array}{l}\text { 17. Sharing economy } \\
\text { 18. Governments and the } \\
\text { blockchain } \\
\text { 19. 3-D printing and manufacturing } \\
\text { 20. 3-D printing and human health } \\
\text { 21. 3-D printing and consumer } \\
\text { products } \\
\text { 22. Designer beings } \\
\text { 23. Neurotechnologies }\end{array}$ \\
\hline
\end{tabular}


Industrial Revolution, they should be actively applied to the development of venture and small- and medium-sized companies.

\section{Conclusion}

The global economy is trying to recover to a new vibrant economy by creating new demands and new labour market for the young generation. These attempts are called the Fourth Industrial Revolution.

In the Fourth Industrial Revolution, a customer may be someone who does not physically experience products or services. Even those who can potentially become customers in the future should also be included in the category of customers.

Eventually, the new technologies (IoT, AI, AR) will create a blue ocean with a combination of removal, reduction, growth and creativity, and further, innovation initiatives of openness and convergence for opening a new ecosystem.

This paper had explored the link between open innovation and convergence for the vibrant economic innovation that will come to the Fourth Industrial Revolution. Along with the relevance of these three words and the best practices, we have formulated policies to realize the vitality of the economy.

Firstly, it is to deregulate new businesses competing most efficiently in free markets without artificial restriction. Secondly, it is necessary to secure the expertise of knowledge labour by acquiring the latest information and business knowledge as well as devoting oneself to work activities to improve the value of an organization. Thirdly, it is to support enhancing the capability of new convergence technologies for the efficiency of new industries. Lastly, it is to support venture firms in obtaining variety of external knowledge, which is essential to secure the professionalism of the knowledge work.

Predicting the future is not simple. We do not know how the world will turn into, as it feels differently whether the rapid change is an opportunity or a threat. In conclusion, however, by the advent of the Fourth Industrial Revolution, this paper will help to bring new policies for the technological, industrial, and economic orientation to alleviate the global economic crisis based on dynamic economy.

\section{Endnotes}

${ }^{1}$ Recognition of changes in the surrounding environment such as in pressure, acceleration, temperature, frequency, and biosignal.

2“External search breadth" refers to the number of external knowledge sources used for organizational innovation activities, and "external search depth" refers to the depth of the external knowledge sources used for organizational innovation activities.

${ }^{3} \mathrm{KT}$ 's service that rents the ERP (Enterprise Resource Planning) function to phone users.

Author's contributions

The author introduces the importance of links between convergence and open innovation for the creation of demand and new labor market through a dynamic economy caused by the Fourth Industrial Revolution. 


\section{Publisher's Note}

Springer Nature remains neutral with regard to jurisdictional claims in published maps and institutional affiliations.

Received: 4 July 2017 Accepted: 30 October 2017

Published online: 21 November 2017

\section{References}

Baweja, B., Donovan, P., Haefele, M., Siddiqi, L., \& Smiles, S. (2016). Extreme automation and connectivity: The global, regional, and investment implications of the Fourth Industrial Revolution. UBS White Paper for the World Economic Forum Annual Meeting 2016. http://mww.tadviser.ru/images/b/b7/Extreme_automation_and_connectivity_The_global\%2C_regional\%2C_ and_investment_implications_of_the_Fourth_Industrial_Revolution.pdf.

Chae, H. S., Choi, Y. Y., \& Huh, E. J. (2014). Venture firm's open innovation: Strategy for external knowledge search and innovation performance of domestic manufacturing industry. Asia-Pacific Journal of Business Venturing and Entrepreneurship, 9(1), 1-13.

Chesbrough, H. (2003). Open innovation. Boston: Harvard Business Press.

Coase, R. H. (1937). The nature of the firm. Econometrica, 4(16), 386-405 http://links.jstor.org/sici?sici=00130427\%28193711\%292\%3A4\%3A16\%3C386\%3ATNOTF\%3E2.0.CO\%3B2-B.

Cooke, P. (2016). The virtues of variety in regional innovation systems and entrepreneurial ecosystems. Journal of Open innovation: Technology, Market, and Complexity, 2(13), 1-19. https://doi.org/10.1186/s40852-016-0036-x.

Ghemawat, P. (2007). Managing differences: The central challenge of global strategy. Boston: Harvard Business Press.

Jang, Y. J. (2016). The fourth industrial revolution and the tasks of Korean industries. In Sicheong-daero. Sejong: KIET Industrial Economy.

Kang, W. J., Lee, B. H., \& Oh, W. G. (2012). The effects of the utilization of external resources on the technological innovation performance along the stages of growth in Korean ventures. Asian Pacific Journal of Business Venturing and Entrepreneurship, 7(1), 34-35.

Kelly, K. (1997). Twelve principles of the network economy. Wired.

Kim, S. Y. (2016) Soft Power as major engine if the Fourth Industrial Revloution, Issue Report of POSRI(Posco business research Institute)

Kodama, F., \& Shibata, T. (2015). Demand articulation in the open-innovation paradigm. Journal of open innovation: Technology, Market, and Complexity, 1(2), 1-21. https://doi.org/10.1186/s40852-015-0003-y.

Laursen, K., \& Salter, A. (2006). Open for innovation: The role of openness in explaining innovation performance among UK manufacturing firms. Strategic Management Journal, 27(2), 131-150. https://doi.org/10.1002/smj.507.

Lee, J. W. (2016). The fourth industrial revolution: Based on major nations' response status. In Jung-gu. Seoul: The Bank of Korea. Lee, S.M., \& Olson, D.L., (2011). Convergenomics.

Lee, S. M., Olson, D. L., \& Trimi, S. (2011). Co-innovation: Convergenomics, collaboration, and co-creation for organizational values. Management Decision, 50(5), 817-831. https://doi.org/10.1108/00251741211227528.

Lee, S. Y. (2017). Busan needs to formulate the strategies of the fourth industrial revolution with the rapidly changing waves. Busan Development Forum, 163, 36-49.

Ministry of Education. (2016). Flexible education system for creativity in university Plan of improving the college system (December 2016)

Park, H. S. (2016). New technology trends and government's response direction. Technology Innovation and Future Busan (Summer), 42-45

Regulatory Reform Committee. (2016). Deregulation to improve the competitiveness of new business Regulatory Reform White Paper.

Science and Technology Policy Institute. (2012). Korean Innovation Survey, 2010 http://eng.stepi.re.kr/index_eng.jsp. Accessed 1 March 2013.

Yun, J. H. J., Park, K. B., Yang, J. H., \& Jung, W. Y. (2016). The philosophy of "open innovation". Journal of Science and Technology Policy Management, 7(2), 134-153. https://doi.org/10.1108/JSTPM-08-2015-0030.

Yun, J. H. J., Won, D. K., \& Park, K. B. (2016). Dynamics from open innovation to evolutionary change. Journal of Open Innovation: Technology, Market, and Complexity., 2(7), 1-22. https://doi.org/10.1186/s40852-016-0033-0.

Submit your manuscript to a SpringerOpen ${ }^{\circ}$ journal and benefit from:

- Convenient online submission

- Rigorous peer review

- Open access: articles freely available online

- High visibility within the field

- Retaining the copyright to your article

Submit your next manuscript at $>$ springeropen.com 